\title{
DIABETES: EMERGING PANDEMIC
}

\author{
Agrawaal $\mathrm{KK}^{1}$, Chaudhary $\mathrm{S}^{2}$
}

\section{Editor 2. Executive Editor}

Diabetes has emerged as a huge problem that the world is facing. The newer challenges in diabetes are not only confined to the glycemic control but rather to the metabolism as a whole. This holds true on the new lipogenic model of diabetes. ${ }^{1}$ As per the International Diabetes Federation, the latest estimates indicate that there are 382 million people living with diabetes worldwide. By 2035, 592 million people or one person in ten will have the disease. A further 316 million people are currently at high risk of developing type 2 diabetes with the number expected to increase to almost 500 million within a generation. In South East Asia one in twelve have diabetes. $^{2}$

In a nationwide hospital based study conducted by the Nepal Health and Research Council, the prevalence of Diabetes was $19 \%{ }^{3}$ In a study done by Nepal Diabetes Association the prevalence of diabetes in the people 20 years and above was estimated to be $14.6 \%$ and $2.5 \%$ in urban and rural areas respectively. ${ }^{4}$ Similarly in a community based study in Eastern Nepal the prevalence of diabetes was $6.3 \%$ whereas the prevalence of metabolic syndrome was $23 \%{ }^{5}$ The risk of developing Type 2 Diabetes increases by 5 times in patients with metabolic syndrome. Thus the primary care physicians should shift the paradigm from being diabetologist to metabologist. This is important if we want to stop the ticking of this pandemic bomb of type 2 diabetes. Our neighboring country has already completed a nationwide both hospital and community based survey and the final results are soon to be published. ${ }^{6}$ This not only encourages but also forces our government to have a nationwide survey on the prevalence of this disease to know its true impact in terms of both health and our economy.

Nepal is the third poorest country in Asia which is the home for most number of Diabetes in the world. As per the World Bank Nepal ranks $157^{\text {th }}$ out of 187 countries listed in the human development index. ${ }^{7}$ There is a huge impact on the country's economy on the Diabetes. The total spending on diabetes is about US $\$ 612$ billion which is $11 \%$ of worldwide healthcare expenditure. ${ }^{8}$ The strategies on preventing the disease and detection of complications at the earliest at the primary level are more important. Strategies like detecting retinopathy earlier and treating them saves the Disability Adjusted Life Years.' Similarly detecting nephropathy earlier and delaying the progression will decrease the burden on government's funding for Renal Replacement Therapy. We recommend a strategy to go to the primary level rather than the super speciality. For this we can look at the model in different parts of the world where the focus is on primary level care providers by training them, having regular workshops and seminars on diabetes education and management. Most importantly the role of diabetes educators has come up. We also request the academia to start online courses and provide training opportunities to the physicians to provide a better care as they are the backbone of the health system of any country.

Lastly the IDF has declared 2014 as the first of the three years focusing on healthy living and diabetes. On behalf of the world Diabetes Day campaign we recommend our readers to "Make healthy food the easy choice and have Healthy eating by making the right choice."

\section{REFERENCES}

1. Unger RH. Reinventing type 2 diabetes: pathogenesis, treatment, and prevention. JAMA. 2008; 299(10): 11851187. http://dx.doi.org/10.1001/jama.299.10.1185 PMid:18334695

2. International Diabetes Federation. IDF diabetes atlas sixth edition update. International Diabetes Federation 2014.

3. Nepal Health Reasearch Council. Prevalence of Non Communiable Disease in Nepal Hospital Based study. NHRC 2010.

4. Nepal Diabetes Association[Internet].Kathmandu: Nepal Diabetes Association;2014. Available from: www.nepal diabetesassociation.com/research.php.

5. Sharma SK, Ghimire G, Radhakrishnan J,Thapa L,Shrestha NR et al. Prevalence of Hypertension, Obesity, Diabetes and metabolic Syndrome in Nepal. International Journal of Hypertension; 2011.http://dx.doi.org/10.4061/2011/821971 PMid:21629873 PMCid:PMC3095978

6. Anjana RM, Ali MK, Pradeepa R, Deepa M, Datta M, Unni krishnan etal. The need for obtaining accurate nationwide estimates of diabetes prevalence in India-Rationale for a national study on diabetes. Indian JMed Res: April 2011(133). Pg.369-80. PMid:21537089 PMCid:PMC3103169

7. World Bank [Internet]: World Bank; 2013.Available from: www. worldbank.org/en/country/nepal/overview

8. International Diabetes Federation [Internet].Brussels: International diabetes Federation;2014 .Available from: www.idf.org.

9. Sahay R, Baruah MP, Kalra S. Health economics in India: The case of diabetes mellitus. Indian Journal of Endocrinology and Metabolism; Mar-Apr 2014 vol.18 (2).pg. 135-37. http://dx. doi. org/10.4103/2230-8210.129101 PMid:24741506 PMCid:PMC3987260 